International Journal of Instruction e-ISSN: 1308-1470 • www.e-iji.net

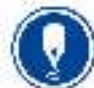

July $2021 \bullet$ Vol.14, No.3

p-ISSN: 1694-609X

pp.909- 928

Article submission code:

20200625113340

Received: 25/06/2020

Revision: 02/02/2021
Accepted: 25/02/2021

OnlineFirst: 23/06/2021

\title{
Project Based E-Learning and Academic Procrastination of Students in Learning Chemistry
}

\section{Wayan Santyasa}

Universitas Pendidikan Ganesha, Indonesia, santyasa@yahoo.com

\section{Ketut Agustini}

Universitas Pendidikan Ganesha, Indonesia,eghee2006@gmail.com

Ni Wayan Eka Pratiwi

Universitas Pendidikan Ganesha, Indonesia, echatika29@gmail.com

Chemistry learning in high school should encourage the application of knowledge learned to solve real-world problems around students without delay. This study aimed at analyzing the effect of the project based e-learning model $(\mathrm{PjBeL})$ compared to direct e-learning (DeL) and academic procrastination (AP) on students' critical thinking skills and cognitive achievement. This quasiexperimental research used the pretest-posttest nonequivalent control group design. The study population was 5 classes (148 students) XI MIPA of SMAN 1 Bebandem. The sample was selected using the class rendom technique to determine 4 classes (120 students, or $81.1 \%$ of the population) as reseach samples. This technique is also used to determine 2 classes as the experimental group and the other 2 classes as the control group. Academic procrastination data were collected by using questionnaires, critical thinking skills data with essay tests, while learning achievement data with expanded multiple choice tests. The data were analyzed descriptively and multivariate analysis of covariance. The results showed that, (1) there were differences in critical thinking skills and student achievement between students who studied with those models, in which the students who studied with the PjBeL model showed a better result. (2) The differences of students' AP had an impact on students' achievement, but did not affect the achievement of their critical thinking skills. students with low academic procrastination (LAP) achieve higher learning achievement than those with high academic procrastination (HAP). (3) There is no interactive effect between the learning model ( $\mathrm{PjBeL}$ v.s DeL) and academic procrastination (LAP v.s HAP) on both student achievement and critical thinking. The implication of this research is that in achieving students' achievement and their critical thinking, chemistry learning will be better using PjBeL.

Keywords: project based e-learning, direct e-learning, academic procrastination, critical thinking skills, and student achievement

Citation: Santyasa, I. W., Agustini, K., \& Pratiwi, N. W. E. (2021). Project Based E-Learning and Academic Procrastination of Students in Learning Chemistry. International Journal of Instruction, 14(3), 909-928. https://doi.org/10.29333/iji.2021.14353a 


\section{INTRODUCTION}

One of the problems of learning chemistry in high school is the lack of learning activities that encourage students to apply the knowledge learned to solve real-world problems around them that will give meaning to them. Students are asked to practice solving problems independently at home, without being directed to complete projects that are relevant to learning. As a result, students only know the concept but cannot apply it in solving questions or problems. Chemistry learning in high schools tends to use a direct instruction model that minimizes student involvement actively in learning (Experenza, et al., 2019). This opinion is supported by Ihsan, et al., (2019) which stated that chemistry learning has not facilitated the students to practice critical thinking skills, the methods used are still conventional, teacher-centered learning, the lack of technology usage, worksheet as teaching material so that students' experience difficulties in developing their thinking ability.

The impact of that chemistry learning process is the results of Program for International Student Assessment (PISA) 2018 showed that Indonesia placed 70th rank out of 78 countries with an average score of 396 (OECD, 2019). In addition, the average score of the high school chemistry national examination (NE) results in 2019 was 50.99 (Puspendik, 2019). The results of the PISA and the NE showed that Indonesian students' ability in answering questions that refers to critical thinking skills, logical and problem solving in mathematics and science was still very low. This is supported by the research of Dewi \& Azizah (2019) also showed students' critical thinking skills are low so they recommend critical thinking skills to be trained using appropriate learning models and teaching materials. In addition, according to Nurkhaliza et al. (2018), students had not been accustomed to solving problems and were accustomed to being given low levels of questions, therefore they had not practiced students' critical thinking skills. Ennis (1996) stated that students who have good critical thinking skills have a good understanding of the concept of science. In addition, the study of Danial \& Sulastri's (2019) showed that critical thinking skills had a causal correlation with mastery of chemical concepts.

In accordance with the data above, it is now important to change the chemistry learning process to improve critical thinking skills and student achievement. The learning process must be relevant to the era of the industrial revolution 4.0 and can be carried out online to address the lack of face-to-face exposure due to the spread of coronavirus disease (Covid-19). To change the process of learning chemistry, the teacher cannot change the learning time in class because it is in accordance with curriculum rules, yet, the learning model can be changed. The model selected must be in accordance with the characteristics of chemistry and be able to maximize the learning for activities that encourage critical thinking skills and student chemistry learning achievement.

Optimal learning can be obtained if a teacher has a certain amount of knowledge, to set learning objectives, make evaluation tools, choose relevant subject matter, design learning experiences, and most importantly be able to integrate them into technology (Agustini, Santyasa, \& Ratminingsih, 2019). They claim that technology will provide students with learning to set their own place and time, where and when students can work on their learning projects. For this reason, this study applied a project based e- 
learning (PjBeL) model. This model was expected to optimize the learning process by utilizing technology and encourage students to work on projects related to learning, so that the critical thinking skills and learning achievement of the students increase. The research on the integration of $\mathrm{PjBL}$ with e-learning strategies had been conducted by Widyaningsih \& Yusuf (2019) in which the results of this model gave impact on the improvement of students' learning outcomes, students' responses positively to the learning process, and the learning atmosphere was fun. In addition, Safitri \& Suparwoto (2018) found that project-based e-learning was effective in enhancing students' creative thinking skills in learning physics with the material was Newton's law of motion in high school.

Undeniably, learning in the classroom is also influenced by the academic procrastination of students, including learning with a project based e-learning model. Solomon \& Rothblum (1985) stated that academic procrastination is a tendency to delay in starting or completing the whole academic tasks to cconduct other activities that are not useful. Research of Santyasa et al., (2020) on physics subjects showed significant differences in academic achievement between students who have high academic procrastination (HAP) and low academic procrastination (LAP). Students with low academic procrastination (LAP) have higher learning achievement and there is an interactive effect between learning models and academic procrastination on student academic achievement. This finding showed that academic procrastination has an effect on learning achievement, including in chemistry subjects, so it must be considered in improving the learning process.

The influence of the PjBeL model and the students' academic procrastination applied in chemistry learning to critical thinking skills and student achievement in class XI cannot yet be revealed. Therefore, this study will examine the effect of $\mathrm{PjBeL}$ and academic procrastination on critical thinking skills and chemistry learning achievement of class XI high school students.

\section{Project Based E-Learning}

The definition of project-based learning has been revealed by several experts including Barron et al., 1998; Wena, 2011; Craft \& Caproro, 2017; Santyasa; 2017. In essence they state project-based learning is learning that deepens knowledge and skills by indepth investigation of a real-world topic within a certain period of time, focusing on problems and producing products. Project based learning models are implemented with the following steps: 1) start with the essential question, 2) design a plan for the project, 3 ) create a schedule, 4) monitor the students and the progress of the project, 5) assess the outcome, and 6) evaluate the experience (The George Lucas Educational Foundation, 2007).

In order to be relevant to the era of the industrial revolution 4.0 and can be carried out online without face to face due to the spread of coronavirus disease (covid-19), the PjBL model is integrated with e-learning strategies. E-learning can be classified into three categories namely adjunct, mixed / blended and fully online (Rashty in Chaeruman, 2017). In this study the e-learning applied is fully online. Naidu (2006) states there are 2 settings for e-learning namely synchronous learning and asynchronous learning. In this 
study applying asynchronous learning in the form of independent asynchronous and collaborative asynchronous. Horton (2006) explains the e-learning flow in three cycles, namely absorb, do and enact. Absorb is an activity that allows participants to absorb information through seeing and hearing. Do is an activity that allows participants to actively learn to do exercises, explore, and discover. Connect is an activity that allows participants to learn to relate or apply what they have learned to real situations (application in actual work).

The PjBeL model is a learning model that combines PjBL with e-learning strategies. The PjBeL model is learning that deepens knowledge and skills by in-depth investigation of a real-world topic within a certain period of time, focusing on problems and producing products that are implemented with e-learning strategies. The use of elearning at $\mathrm{PjBL}$ aims to provide learning facilities for students because every material and assignment can be accessed online whenever and wherever they are. PjBeL learning steps are obtained by combining the syntax of the PjBL model with e-learning flowcharts such as Table 2.1 (adapted from The George Lucas Educational Foundation (2007) and Horton (2006))

Table 1

Steps in PjBeL learning

\begin{tabular}{lll}
\hline E-learning flow & Learning activities & Asynchronous Type \\
\hline Absorb & Listening to digital material in google classroom & independent \\
\hline Do & Work on student worksheets & Collaborative and independent \\
\hline Enact & $\begin{array}{l}\text { Project-based learning: start with the essential question, } \\
\text { design a plan for the project, create a schedule, monitor } \\
\text { the students and the progress of the project, assess the } \\
\text { outcome, evaluate the experience }\end{array}$ & \\
\hline
\end{tabular}

\section{Academic Procrastination}

Academic procrastination is a type of delay that is done on the type of formal task related to the academic field (Ferrari, et al.,1995). According to Solomon and Rothblum (1984) academic procrastination defined the tendency shown by individuals to delay academic assignments almost always or always.

Asri, et al., (2017) found that students with HAP have weak personality traits, negative self-image, lack of self-regulation, high anxiety attitudes, weak cognitive, negative learning experiences, weak mental and physical conditions. HAP leads to low learning achievement. Milgram (1991) states that the delay consists of four dimensions which are presented complete with indicators in Table 2.

Table 2

Dimension and indicator of the academic procrastination

\begin{tabular}{lll}
\hline No Dimension & Indicator \\
\hline 1. A series of delaying behaviors & Delay in academic assignments \\
\hline 2. & Produce substandard behavior & Lags in working on tasks \\
\cline { 2 - 3 } & Time gap between plan and actual performance \\
\hline $\begin{array}{ll}\text { 3. } \\
\text { Involves a number of tasks that are perceived as } \\
\text { important for procrastinators }\end{array}$ & Do other activities that are more fun \\
\hline 4. & Produce an unpleasant emotional state & Emotional anxiety \\
\hline
\end{tabular}

Source: Lindblom-Ylännea et al. (2015) 


\section{Critical Thinking Skills}

Rowe, et al., (2015) defines critical thinking as the ability to draw reasonable conclusions based on evidence, logic, and intellectual honesty. Ennis (2013) defines critical thinking as sensible reflective thinking that focuses on deciding what to believe or do. The critical thinking skills test was developed based on the rubric of critical thinking skills by Ennis (2013) and adapted to Bloom's Anderson text revision range of economics namely applying (C3), analyzing (C4) and evaluating (C5). Indicators of critical thinking skills in research are presented in Table 3.

Table 3

Indicators of critical thinking skills in research

\begin{tabular}{ll}
\hline $\begin{array}{l}\text { Dimensions of Critical } \\
\text { Thinking Skills }\end{array}$ & Indicator \\
\hline Formulate the problem & $\begin{array}{l}\text { 1.The problem formulation is in accordance with the narrative of the } \\
\text { problem } \\
\text { 2.Formulate in the form of questions that give directions to obtain answers }\end{array}$ \\
\hline Give an argument & $\begin{array}{l}\text { 1.Arguments with suitable reasons. } \\
\text { 2.Show differences and similarities. }\end{array}$ \\
\hline Do deduction & $\begin{array}{l}\text { 1.Logically deduct. } \\
\text { 2.Interpreting questions }\end{array}$ \\
\hline Do induction & $\begin{array}{l}\text { 1.Conduct complete investigation/data collection } \\
\text { 2.Make generalizations from data, make tables, and graphs }\end{array}$ \\
\hline Evaluating & $\begin{array}{l}\text { 1.Provide solutions / suggestions according to the problem } \\
\text { 2.Providing alternatives in accordance with the theory }\end{array}$ \\
\hline Decide and implement & 1.Choosing possible alternatives. \\
& 2.Determine the possible solutions that will be implemented based on theory \\
\hline
\end{tabular}

\section{Student Achievement}

Learning achievement is learning as the level of student success in achieving the goals set in a teaching program (Shah, 1995). Arifin (2009) states learning achievement is generally concerned with aspects of knowledge. Learning achievement is an educational assessment of student progress in everything that is learned in school that involves knowledge or skills that are stated after the results of the study (Djamarah, 1994). Learning achievement is influenced by internal and external factors. Internal factors are factors that exist in individuals who are learning, while external factors are factors that exist outside the individual. Internal factors include physiological factors, intelligence or intelligence, talents, interests, attention, student motivation and student attitudes. External factors include family, school and community environment (Slameto, 2003). Learning achievement in this study is influenced by the learning model factors applied and students' academic procrastination. Cognitive domain learning achievements are based on revised bloom taxonomy with a minimum achievement level equal to basic competency achievement.

\section{METHOD}

\section{Model of Research}

This research is a quasi experimental with the pre test-post test control group design. Quasi experimental design seeks to reveal the cause and effect relationship by involving 
the control group in addition to the experimental group. Quasi-experimental research conducted as a result of complete randomization cannot be carried out perfectly, so controlling the independent variables can be carried out only in very limited quantities. However, using the right methodology, the results of quasi experiments can still be scientifically justified.

\section{Population and Sample}

The population in this study were 5 classes (or 148 students) in grade XI MIPA in SMAN 1 Bebandem in Even Semester in the Academic Year of 2019/2020. The five classes are academically homogeneous, because when the formation of each class is done randomly. So the random sampling technique can be used to determine four classes as samples, namely class XI MIPA 1, XI MIPA 2, XI MIPA 3 and XI MIPA 4, each of 30 students, as samples. Then the 4 classes are drawn to determine 2 classes (XI MIPA 1 and XI MIPA 2) as an experimental class that will be taught with the PjBeL model and 2 classes (XI MIPA 3 and XI MIPA 4) as a control class learned with DeL. For data analysis purposes, students in the control and experiment classes are each divided into two categories, namely groups of students with high academic procrastination (HAP) and low academic procrastination (LAP). Determination of academic procrastination in both the control group and the experimental group was carried out using a questionnaire. Scores obtained from the procrastination questionnaire were ranked, as many as 33\% of the upper group (20 students) stated as those with HAP, while 33\% the lower group (20 students) as the group with LAP.

\section{Data Collection and Analysis}

In this study 35 items of academic procrastination questionnaire were developed on a scale of 1-4. Before being used, the questionnaire was tested to analyze the internal consistency of items using product moment correlation and its reliability was determined using Cronbach's Alpha (Candiasa, 2010). Thirty items were obtained as suitable for use in this study. The reliability of 30 items from the academic procrastination questionnaire was 0.824 including the very high category.

Critical thinking skills tests are in the form of essay tests and achievement tests in the form of expanded multiple choice tests, each consisting of 22 items using rubrics with a measurement scale of 0-5 for each item. Before the test is used, the two tests are first tested. After being tested and considering content validity, internal consistency of test items, different power indexes, item difficulty index and test reliability, the two types of tests were each assigned 15 items as research instruments. The reliability of the 15 items of the critical thinking skills test was 0.907 , and the reliability of the 15 items of the student achievement test was 0.888 , each including a very high category.

The data analysis technique used is descriptive analysis and multi-covariance (multivariate analysis of covariance/mancova). Before testing the hypothesis, the assumption test is performed, namely 1) the variance homogeneity test, 2) the normality test, 3) the regression linearity test; 4) the significance of the regression test, and 5) multicollinearity test. All assumption tests are conducted at a significance level of 5\%. 


\section{FINDINGS}

\section{Descriptive Analysis Results}

Data about average value and standard deviation of critical thinking skills and students' initial achievement from the results of the pretest (covariate) and critical thinking skills and student achievement from the results of the posttest (dependent variable) in 4 groups are presented as follows.

Table 4

Mean (M) and standard deviation (SD) students' critical thinking (CT) and students' achievements (SA) both PjBeL and DeL each for the low academic procrastination (LAP) and high academic procrastination (HAP)

\begin{tabular}{|c|c|c|c|c|}
\hline \multicolumn{5}{|c|}{ Critical Thinking Skill (CT) } \\
\hline & PjBeL & & DeL & \\
\hline SOURCE & Pre-test & Post-test & Pre-test & Post-test \\
\hline \multirow{2}{*}{ HAP } & $M=17.75$ & $\mathrm{M}=44.90$ & $\mathrm{M}=17.80$ & $M=36.35$ \\
\hline & $\mathrm{SD}=3.51$ & $\mathrm{SD}=6.15$ & $\mathrm{SD}=3.68$ & $\mathrm{SD}=5.79$ \\
\hline \multirow{2}{*}{ LAP } & $\mathrm{M}=20.00$ & $M=46.75$ & $\mathrm{M}=19.50$ & $\mathrm{M}=41.40$ \\
\hline & $\mathrm{SD}=4.33$ & $\mathrm{SD}=6.96$ & $\mathrm{SD}=2.78$ & $\mathrm{SD}=5.85$ \\
\hline \multicolumn{5}{|c|}{ Student Achievement (SA) } \\
\hline & \multicolumn{2}{|l|}{$P j B e L$} & \multicolumn{2}{|l|}{ DeL } \\
\hline SOURCE & Pre-test & Post-test & Pre-test & Post-test \\
\hline \multirow{2}{*}{ HAP } & $M=5.75$ & $\mathrm{M}=38.35$ & $\mathrm{M}=4.75$ & $M=30.60$ \\
\hline & $\mathrm{SD}=4.48$ & $\mathrm{SD}=6.06$ & $\mathrm{SD}=2.31$ & $\mathrm{SD}=6.97$ \\
\hline \multirow{2}{*}{ LAP } & $\mathrm{M}=12.10$ & $\mathrm{M}=47.65$ & $\mathrm{M}=7.20$ & $\mathrm{M}=38.00$ \\
\hline & $\mathrm{SD}=9.05$ & $\mathrm{SD}=5.82$ & $\mathrm{SD}=5.88$ & $\mathrm{SD}=9.11$ \\
\hline
\end{tabular}

The bar diagram of the 4 groups critical thinking skills and student achievement is presented in Figure 1.

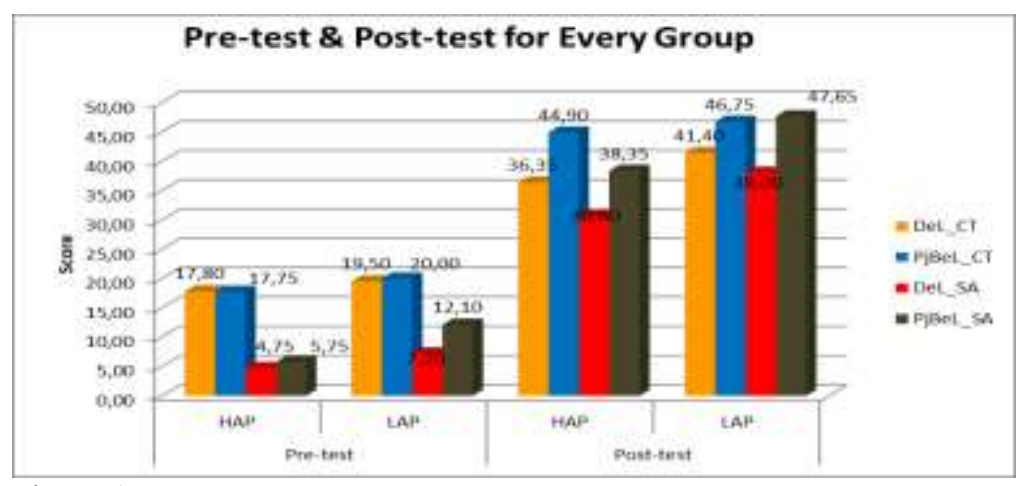

Figure 1

Students' critical thinking skills and students' achievement on the four groups

Research data shows that before and after the treatment of students' critical thinking skills in the PjBeL-HAP group and the PjBeL-LAP group increased from less good categories to good categories on HAP and very good on LAP, while DeL-HAP groups 
and DeL-LAP groups increased from not good categories to good category both on HAP and LAP. In addition, the research data shows that before and after the treatment, the student achievement in the PjBeL-HAP group and the PjBeL-LAP group increased from the category of very poor to good category on HAP and very good on the LAP, while the DeL-HAP group and the DeL-LAP group increased from not good category to good enough category in HAP and good category in LAP.

\section{Assumption Test Results}

Homogeneity testing of variance between independent groups shows that the statistical significance of the Leven's Test of Equality of Error Variance is greater than 0.05. This means that the variance between learning models in all units of analysis is homogeneous.

Normality test was done using Kolmogorov-Smirnov test and the Shapiro-Wilks test (Candiasa, 2010). The tests were carried out on pre-test and post-test data on 4 analysis groups (PjBeL-HAP, PjBeL-LAP, DeL-HAP, DeL-LAP). The result shows that the posttest data has sig $>0.05$, which means the data is normally distributed.

The result of the analysis shows the significance value of all data on deviation from linearity $>0.05$, means that the regression direction from the covariate to the dependent variable is linear. Thus, an increase in covariate prices will be followed by an increase in prices on the dependent variable and vice versa. In addition, the Linearity significance value $<0.05$, means that is the form of linear regression. Collinierity testing shows tolerance value $>0.10$ and VIF value $<10$, means that there are no symptoms of collinearity in the regression model.

Table 5

Summary of MANCOVA analysis results

\begin{tabular}{lllrlrc}
\hline Source & $\begin{array}{l}\text { Dependent } \\
\text { Variable }\end{array}$ & $\begin{array}{l}\text { Type III Sum } \\
\text { of Squares }\end{array}$ & df & $\begin{array}{l}\text { Mean } \\
\text { Square }\end{array}$ & F & Sig. \\
\hline LEARNMO & SA & 1242.075 & 1 & 1242.075 & 24.255 & 0.001 \\
\hline & CT & 770.295 & 1 & 770.295 & 23.761 & 0.001 \\
\hline ACAPRO & SA & 921.292 & 1 & 921.292 & 17.991 & 0.001 \\
\hline & CT & 48.952 & 1 & 48.952 & 1.510 & 0.223 \\
\hline ACAPRO*LEARNMO & SA & 6.123 & 1 & 6.123 & 0.120 & 0.731 \\
\hline & CT & 84.808 & 1 & 84.808 & 2.616 & 0.110 \\
\hline
\end{tabular}

Based on the results of the MANCOVA analysis in table 5, the results are as follows. Firstly, from the effect of learning model (LEARNMO) on the student achievement (SA), its show that $\mathrm{F}=24.255$ which has a significant value of 0.001 lower than 0.05 . So that the Ho is rejected or Ha is accepted. It means that there is a significant different of SA between them learn in the PjBeL and DeL. The SA of student learn in the PjBeL model $(M=43.00 ; S D=7.52)$ is higher than the learn in the DeL model $(M=34.30$; $\mathrm{SD}=8.84)$.

Secondly, F value of the effect of the LEARNMO on critical thinking (CT) skills shows that $\mathrm{F}=23.761$. The $\mathrm{F}_{(\text {table;0.05) }}=3.94$. It turned out that $\mathrm{F}>\mathrm{F}_{(\text {table;0.05) }}$ or a significance value of $0.001<0.05$. Based on these results, the CT skills between students who learn with the $\mathrm{PjBeL}$ model and students who learn with the DeL model is significantly 
different. The student $\mathrm{CT}$ who learn in the PjBeL model $(\mathrm{M}=45.83$; $\mathrm{SD}=6.54)$ is higher than the learn in the DeL model $(M=38.88 ; \mathrm{SD}=6.37)$.

Thirdly, the F value of the effect of academic procrastination (ACAPRO) on SA shows $F=17.991$ while the $F_{(\text {table; 0.05) }}=3.94$. It turned out that $F>F_{(t a b l e ; 0.05)}$ or a significance value of $0.001<0.05$. These results indicate that Ho is rejected and $\mathrm{Ha}$ is accepted. This means that there are significant differences in learning achievement between students with HAP and students with LAP. The SA of students have LAP (M = 42.83; SD = $8.99)$ is higher than them have $\mathrm{HAP}(\mathrm{M}=34.48 ; \mathrm{SD}=7.55)$.

Fourthly, the F value of the effect of ACAPRO on CT skills shows F $=1.510$, while the value of $F_{(\text {table;0.05) }}=3.94$. It turned out that $F<F_{(\text {table;0.05) }}$ or a significance value of 0.223 $<0.05$. These results indicate there is no significant difference in critical thinking skills between students with HAP and students with LAP.

Fiftly, the F values of the interactive effect between ACAPRO (LAP v.s HAP) and LEARNMO (PjBeL V.S DeL) on SA shows $F=0.120$ and on CT skills shows $F=$ 2.616. Both turned out that $\mathrm{F}<\mathrm{F}_{(\text {table;0.05). }}$ These results indicate that Ho is accepted, so there ar not interactive effect between learning model (PjBeL v.s DeL) and academic procrastination (LAP v.s HAP) on both of SA and CT skills. That means PjBeL is accommodating both for students who have HAP and for those who have LAP, as well as DeL.

\section{DISCUSSION}

The Impact of Project Based E-Learning (PjBeL) and Directs E-Learning (DeL) on Critical Thinking Skills and Student Achievement

The result is a difference in critical thinking skills and learning achievement between students who study with PjBeL and students who study with DeL. The results of further analysis show the achievement of critical thinking skills and greater learning achievement in students who study with PjBeL compared to DeL. The results of this study are in line with the results of Febrianita's research (2019), that there are differences in critical thinking skills between students who learn with project-based blanded learning and students who learn by direct learning models with better results on learning with project-based blanded learning. Putri, et al., (2019) who stated that students' critical thinking skills were better in the experimental class applying projectbased learning compared to students in the control class applying conventional learning. Rajan, et al., (2019) who found that project-based learning could lead to increased motivation and increase students' critical thinking better than conventional learning. Safitri \& Suparwoto (2018) who found that project-based e-learning was effective for improving students' creative thinking skills in learning physics. Santyasa, et al., (2020) who found that students who learn in the project based learning model have higher academic achievement compared to students who learn in direct instruction. Widyaningsih \& Yusuf (2019), that learning outcomes, responses and a better learning atmosphere for students who learn with project-based learning $(\mathrm{PjBL})$ are assisted by elearning compared to students who study conventionally. Putra (2017), Mahasneh and 
Alwan (2018), and Yao, et al., (2019), that students who learn with project based learning model have higher academic achievement compared to students who learn with conventional learning.

$\mathrm{PjBeL}$ is a learning model that combines $\mathrm{PjBL}$ with e-learning strategies. The effectiveness of combining e-learning with PjBL has been studied by Abidin, et al., (2020) which results that project-based learning is one of the learning approaches that can maximize online learning. The stages of the e-learning path in this study both $\mathrm{PjBeL}$ and DeL and their contribution to the dependent variable are as follows.

The e-learning path consists of absorb, do, enact. At $\mathrm{PjBeL}$, at the absorbing stage students listen to digital material in google classroom by opening google classroom, downloading the learning video provided, listening and learning the learning video independently and recording important things learned from the video. The material in the learning video is related to acid-base titration. The achievement of this stage is according to the cone of Dale's experience (1969), based on the activities carried out by students the absorption capacity is about $30 \%$ of the total knowledge to be achieved. At this stage students' critical thinking skills have also been stimulated, especially the dimensions of induction by collecting complete data from the video being watched and later utilizing it in project work.

At DeL, in the absorbing stage students open google classroom, download videos containing demonstration of acid-base titration knowledge and skills by their teacher, listen and learn the learning video independently and record important things learned from the video. This learning step is similar to project based e-learning, which differs only in the video presented. In PjBeL the video presented is general, global and does not guide students while in DeL the video is presented in small sections and the video is guided which contain material explanation, practice exercises and how to solve the problem. Because the steps applied are similar, the student achievement is expected to be the same, namely the knowledge achievement around $30 \%$.

At PjBeL, at the do stage, students work on student worksheets in groups. As an example of a project the work of the $\mathrm{PjBeL}$ group students is the titration of materials in their surrounding environment is presented in Table 6. 
Table 6

Example of a project the work of the PjBeL group students

\begin{tabular}{l} 
Group \\
\hline Group 1
\end{tabular}

Students must explore information from the video and literature they have and find solutions to problems provided in student worksheets in groups. The achievement of this stage is according to the cone of Dale's experience (1969) based on the activities carried out by students' absorption ability is about $50 \%$ of the knowledge to be achieved. At this stage students' critical thinking skills begin to be practiced. By working in groups and independently students will begin to learn to do deduction, induction, deciding and implementing which stimulates students' critical thinking skills.

At DeL, at the do stage the students do exercises with student worksheets that are done with the teacher's guidance. The teacher continuously checks understanding and provides feedback through WhatsApp class group discussions. With this stage, students are not given the independence of learning to find their own knowledge and to grow their critical thinking skills. Students will only receive the knowledge given by their teacher without trying to dig in from other sources. Based on this, the acquisition of students' knowledge will not be optimal. 
At $\mathrm{PjBeL}$, at the enact stage students take project-based learning. The projects undertaken by the students through real-world based learning which is done in groups. The achievement at this stage is by working on real-world based learning projects in accordance with the Dale cone (1969) students will be able to absorb at least $90 \%$ of knowledge. This is supported by Sani (2013) who states that project-based learning is applied to deepen the knowledge and skills acquired by making work or projects related to teaching materials and competencies that students expect to have.

Project-based learning provides an opportunity for students to explore material using various methods that are meaningful to them and conduct experiments collaboratively (Wena, 2011). Setting the PjBeL model in a collaborative manner in small groups will enable students to deal with the complexity of opinions with a high degree of difference. This situation will make students do an analysis of the truth of the opinions that exist, describe things related to facts and choose the best alternative solutions and decide the best solution for the given problem. Through discussion in groups, students will indirectly train and develop their critical thinking skills.

Project based learning is learning designed for complex problems, in which students conduct investigations to understand it, emphasizing learning with long-standing activities, assignments given to students are multidisciplinary and product-oriented (Barron et al., 1998). Learning designed for complex problems that encourage this investigation will have an impact on improving learning outcomes, responses to good learning, and a learning atmosphere that feels very pleasant (Widyaningsih \& Yusuf, 2019).

In addition, project-based learning is essentially a learning model that places students as builders of the knowledge they have based on the knowledge they already have. As a result, students become active learners. Students will have high academic involvement during their study with a project-based learning model because they are facilitated with projects that are interesting, challenging, related to the phenomena of daily life and relevant to problems in the community (Craft \& Caproro, 2017).

In addition to encouraging learning achievement, project-based learning will encourage critical thinking skills according to the indicators proposed by Ennis (2013). At the stage of determining the fundamental questions, students will be trained in the ability to formulate problems. In the stages of designing project planning, students will be trained in the ability to do deduction, the ability to decide and implement. At the stage of scheduling, students will be trained in the ability to decide and implement. At the stage of monitoring students and project progress, students will be trained in the ability to evaluate and provide arguments. In the stage of testing the results, students will be trained in the ability to do induction, and provide arguments. In the stage of evaluating experience, students will be trained in the ability to evaluate and provide arguments. After all, $\mathrm{PjBeL}$ can improve the overall achievements of critical thinking skills. This is consistent with the opinion that critical thinking is the ability to draw reasonable conclusions based on evidence, logic, and intellectual honesty (Rowe, et al., 2015). It is also supported by the opinion that critical thinking as sensible reflective thinking that focuses on deciding what to believe or do (Ennis, 2013). 
At DeL, at the enact stage students are given training and the application of concepts in the form of exercises that are done independently. This learning will not be able to encourage the achievement of critical thinking skills and student achievement. DeL ineffectiveness is caused by this model of teachers who are more active and minimize the active involvement of students in learning (Experenza, et al., (2019). This opinion is strengthened by stating that conventional learning strategies including DeL applied in chemistry learning have not facilitated students to train critical thinking skills, the method used is still conventional and teacher-centered learning so that students have difficulty in developing their thinking skills (Ihsan, et al., 2019). Based on this, DeL provides fewer opportunities for students to achieve deep understanding because they only acts as a recipient of knowledge.In-depth understanding can be achieved if the learning process emphasizes the activities of building knowledge and reflective thinking.Thus, the application of the DeL model also lacks opportunities for students to reflect on each learning process. It is important to do an evaluation so that students are able to see their shortcomings as a step to improve the quality of learning.

$\mathrm{PjBeL}$ can encourage students to take on more and more active roles in learning. This is consistent with the theory of constructivism that is student-centered learning. In the learning process, the teacher acts as a facilitator or guide by guiding students in learning without providing assistance in working on the project. In contrast to $\mathrm{PjBeL}$, the implementation of DeL tends to emphasize learning objectives in the form of additional knowledge. This learning model emphasizes on the results so that information from the teacher can be conveyed to students, either through direct instruction, lectures, or assigning exercises to questions without having to pay attention to the relationship of a concept and knowledge with the real life of students themselves. Students are not free to develop their talents and abilities. Really formal learning activities like this are certainly less effective in developing critical thinking skills and student learning achievement.

Based on the explanation, a generalization can be taken that the $\mathrm{PjBeL}$ model is superior to the DeL model in achieving critical thinking skills and student learning achievement. However, in this study critical thinking skills and individual student achievement in $\mathrm{PjBeL}$ have not yet reached the very good category for all students. This is caused by several factors as follows.

First, students have not been able to adjust to the PjBeL model because they are accustomed to following the DeL model. Students do not fully understand the steps of learning activities they have to do. During this time, students are accustomed to getting material directly from the teacher now faced with project-based worksheets and following the steps in the PjBeL model with groups to get knowledge related to the material being discussed. In addition, the appeal at home due to Covid-19, makes it difficult for students to collaborate with their groups in completing their projects. Collaboration between groups is mostly done online through social media so that the achievement of skills and knowledge is not evenly distributed within the group.

Second, according to the conceptual foundation of constructivism learning that students are able to construct knowledge by allocating time that is personal and depends on the cognitive structure of students themselves. All students can achieve their learning goals 
if they are given the opportunity, but will be achieved in different ways and at different depths, and at different speeds. In this study, learning is only done in a short period of time, so that not all students achieve optimal learning outcomes.

Third, group-based learning can trigger students' dependence on their groups. According to Esminarto, et al., (2016) on cooperative learning the success of a group depends very much on each group member. Habits depending on other group members will have an impact on the results of the test implementation because they are accustomed to collaborating with their friends. In addition, in project-based learning that is done with the group, students will focus more on material related to the project being worked on, other material that does not contribute to their project will be ignored.

\section{Impact of Academic Procrastination on Critical Thinking Skills and Student Achievement}

There is no significant difference in critical thinking skills between students with HAP and students with LAP. This is because academic procrastination of both LAP and HAP is both adaptive behavior and maladaptive behavior (Munawaroh, Alhadi, \& Eka Saputra, 2017). It is called maladaptive behavior because academic procrastination has a negative impact on the perpetrator, whereas it is called adaptive because individuals postpone tasks because they want to do the task better. Individuals who have HAP feel they have an advantage when doing academic procrastination because they want to do a better job, so they decide to postpone submitting project assignments. Individuals who have HAP feel they experience a loss when they lose the opportunity to develop better critical thinking skills when working on project tasks, feelings of laziness, and physical exhaustion (Munawaroh, Alhadi, \& Eka Saputra, 2017). It is for this reason that students who have LAP and HAP show the same critical thinking achievement in chemistry learning.

For student achievement, there are significant differences in student achievement between students with HAP and students with LAP. The results of further analysis show greater achievement in students with LAP. Based on this, critical thinking skills are not influenced by AP, while learning achievement is in accordance with AP.

The results of research on the effect of AP on student achievement are in line with the results of research conducted by Hidayat et al. (2018) who found that there was an influence of AP on student learning outcomes. This finding is also supported by Asri, et al., (2017) which states that HAP, leads to low learning achievement. The results of this study are also in line with the study of Santyasa, et al., (2020) who found that the higher a person's AP, the tendency that occurred was a decrease in learning achievement so that higher learning achievement was achieved by students who had LAP. However, relevant research on the effects of AP on critical thinking skills has not been found.

AP is a tendency to delay in starting or completing academic tasks (Solomon \& Rothblum, 1984; Ferrari et al., 1995; Millgram, 1991). Learning in class can not be denied also influenced by the student's AP. This influence occurs because HAP has weak personality traits, negative self-image, lack of self-regulation, high anxiety 
attitudes, weak cognitive, negative learning experiences, weak mental and physical conditions, so students do not immediately feel challenged to do their work (Asri, et al ., 2017; Ojo, 2009; Santyasa, et al., 2020). Students with HAP or LAP according to these characteristics will have an impact on student achievement but do not have an impact on their critical thinking abilities.

Critical thinking is the ability to draw reasonable conclusions about what must be believed or done based on evidence, logic, and intellectual honesty (Ennis, 2013; Rowe, et al., 2015). In this study critical thinking skills are trained by working on projects or challenging tasks. HAP or LAP, does not cause a different impact on critical thinking skills because the delay in doing academic work does not mean that students do not do their academic work. The execution of academic assignments is still carried out in a slow and delayed condition but is eventually resolved. This shows that students' critical thinking in the form of the ability to formulate problems, provide arguments, conduct deduction, conduct induction, conduct evaluations, decide and implement remain trained during the work of the task or project so that task delays will not have an impact on the achievement of critical thinking skills.

AP has an impact on student achievement, HAP causes students to continue to delay learning, especially on material that has nothing to do with the completion of their projects or assignments. This will have an impact on their achievements. This is supported by Slameto (2003) which states that learning achievement is influenced by internal and external factors. Internal factors are factors that exist in individuals who are learning, one of them is the attitude of students.

AP is one of the factors that influences student achievement (Asri, et al., 2017; Santyasa, et al., 2020). The high academic procratination has an impact on students who have low self-regulation, he will continue to delay learning so that his achievement will not be optimal. Conversely, students with LAP rarely or never postpone learning so that optimal learning achievement is achieved (Asri, et al., 2017; Santyasa, et al., 2020).

Based on the explanation, a generalization can be taken that HAP or LAP will have a significant impact on student achievement, but does not have a significant impact on students' critical thinking skills.

Interaction between E-Learning Model (PjBeL versus DeL) and Academic Procrastination on Critical Thinking Skills and Student Achievement

The results of this study indicated the effect of the treatment given (PjBeL versus DeL) on student achievement did not depend on student academic procrastination. This showed that both learning models were accommodative towards students' academic procrastination are high or low.

Wena (2011) stated that project-based learning can accommodate various learning styles owned by the students, by providing opportunities for students to explore material using various methods that were meaningful to themselves and conducting collaborative experiments. It proves that the $\mathrm{PjBeL}$ is accommodative to various learning styles, one of which includes academic procrastination. For the DeL, since students are only 
passively accepting material from their teachers, the proportion of academic procrastination is not very influential.

In addition, the role of e-learning strategies in both models makes both models are accommodative to academic procrastination. It is because e-learning is a method that allows students without time limit to learn the material to understand it and can learn at their own pace (Unala \& Hasturkb, 2019).

Asri, et al., (2017) and Santyasa, et al., (2020) stated several main factors causing academic procrastination including students' assumptions that the assignments given by teachers were not important and not useful for their lives. The application of the PjBeL model based on real world problems causes these factors not to emerge. At DeL, since the teacher provides step-by-step learning and giving relevant examples, these factors can also be overcome. The second factor causing procrastination is the task given by the teacher is too much and the time is limited so that students feel burdensome, it does not occur with the implementation of PjBeL and DeL based on e-learning. The third factor causing procrastination is that students consider the given task is difficult, nor does it occur because the project given is based on the real world. The fourth factor causing procrastination is that students lack the knowledge to be able to do the task, it does not occur with the application of PjBeL and DeL because with the help of e-learning, students can access material online on the internet. Likewise other academic procrastination factors can be accommodated by both models.

Based on the explanation, it can be taken a generalization that both e-learning models (PjBeL versus DeL) are accommodative towards students' academic procrastination either high or low

\section{CONCLUSION}

Based on the results of the analysis, it can be concluded several things. Firstly, there are significant differences of both students' achievement and critical thinking skills between students learn in the PjBeL and DeL models. The students' achievement and their critical thinking skills of them learn in the PjBeL model each is greater than them learn in the DeL model. The implication of this finding is that learning chemistry will be more meaningful if the teacher facilitates student learning with a project-based e-learning model, both in achieving students' achievement and in the development of students' critical thinking skills. Secondly, there is a significant different of students' achievement between them have low academic procrastination and them have high academic procrastination. The students' achievement of students have low academic procrastination is greater than them have high academic procrastination. This means that in learning chemistry, students who often postpone learning should be given a lot of guidance, so that they can gradually improve their discipline to immediately do their learning tasks. However, there is not a significant of student critical thinking skill between the two levels of academic procrastination. Thirdly, there are not interactive iffect of learning model (PjBeL v.s DeL) and academic procrastination (LAP v.s HAP) on the syudents' achievement and as well as their on their critical thinking skill. These have implication that the two learning models accommodative for all levels of the 
students' academic procrastination. Suggestions that can be made from the results of this study are 1) to obtain better students' achievement and their critical thinking skills in learning chemistry, teachers should more intensively study, understand, and apply $\mathrm{PjBeL}$ model in learning. This model should be socialized to students, especially regarding the benefits that can be obtained by students if they learn to use PjBeL. One of the advantages that need to be socialized is that the $\mathrm{PjBeL}$ model can reduce academic procrastination behavior. 2) Teachers need to provide guidance to students to get out of procrastination behavior, by means of individual, classical, and preventive intervention in large class formats. These interventions can be done by focusing on solutions, with guided imagery techniques and applied step by step, encouraging students to imagine themselves thinking, feeling, and behaving in ways that will show they can solve problems without procrastinate.

\section{REFERENCES}

Abidin, Z., Rumansyah, \& Arizona, K. (2020). Pembelajaran online berbasis proyek salah satu solusi kegiatan belajar mengajar di tengah pandemi covid-19 (Project-based online learning is one of the solutions for teaching and learning activities in the midst of the Covid-19 pandemic). Jurnal Ilmiah Profesi Pendidikan, 5(1), 64-70.

Agustini, K., Santyasa, I W, \& Ratminingsih, N. M. (2019). Analysis of competence on "tpack": 21 st century teacher professional development. Journal of Physics: Conference Series, 1387, 1-9

Arifin, Z. (2009). Evaluasi pembelajaran (Learning evaluation). Jakarta: Departeman Agama RI

Asri, D. N., Setyosari, P., Hitipeuw, I., \& Chusniyah, T. (2017). The academic procrastination in junior high school students' mathematics learning: A qualitative study. International Education Studies, 10(9), 70-77

Barron, B. J. S., Schwartz, D. L., Vye, N. J., Moore, A., Petrosino, A., Zech, L., \& Bransford, J. D. (1998). Doing with understanding: Lessons from research on problemand project-based learning. Journal of the Learning Sciences, 7(3-4), 271-311.

Candiasa, I M. (2010). Pengujian instrument penelitian disertai aplikasi iteman dan bigsteps (The research instrument testing was accompanied by the iteman and bigsteps applications). Singaraja: Unit Penerbitan Universitas Pendidikan Ganesha

Chaeruman, U. A. (2017). Pedati-model desain sistem pembelajaran blende: Panduan merancang mata kuliah daring spada Indonesia (Pedati-blended learning system design model: Guide to designing online courses in Indonesia). Jakarta: Direktorat Pembelajaran

Craft, A. M., \& Capraro, R. M. (2017). Science, technology, engineering, and mathematics project-based learning: Merging rigor and relevance to increase student engagement. Electronic International Journal of Education, Arts, and Science, 3(6), 140-158.

Dale, E. (1969). Audio visual methods in teaching. New York: Holt, Rinehart and Winston Inc. The Dryden Press. 
Danial, M., \& Sulastri, T. (2019). Hubungan antara keterampilan berpikir kritis dan metakognisi dengan penguasaan konsep pada beberapa model pembelajaran Kimia (The relationship between critical thinking skills and metacognition with mastery of concepts in several Chemistry learning models). Prosiding Seminar Nasional Lembaga Penelitian Universitas Negeri Makassar. Retrieved 01 November, 2019 from https://ojs.unm.ac.id/ semnaslemlit/article/viewFile /8255/4766.

Dewi, R., \& Azizah, U. (2019). Pengembangan lembar kerja peserta didik (LKPD) berorientasi problem solving untuk melatihkan keterampilan berpikir kritis peserta didik kelas xi pada materi kesetimbangan kimia (Development of problem solving oriented student worksheets (SW) to practice critical thinking skills of class xi students on chemical equilibrium material). Unesa Journal of Chemical Education, 8(3), 332-339.

Djamarah, S. B. (1994). Prestasi belajar dan kompetensi guru (Learning achievement and teacher competence). Surabaya: Usaha Nasional

Ennis, R. H. (1996). Critical thinking. USA: University of Illionis

Ennis, R. H. (2013). The nature of critical thinking: Outlines of general critical thinking dispositions and abilities. Retrieved 02 January, 2020, from http://criticalthinking.net/wp-content/uploads/2018/01/The-Nature-of-Critical-

Thinking.pdf

Esminarto \& Sukowati \& Suryowati, N. \& Anam, K. (2016). Implementasi model stad dalam meningkatkan hasil belajar siswa (Implementation of the standard model in improving student learning outcomes). Jurnal Riset dan Konseptual, 1(1), 16-23.

Experenza, P., Isnaini, M. \& Irmita, L. (2019). Pengaruh model pembelajaran think pair share terhadap keterampilan berkomunikasi siswa pada larutan elektrolit dan non elektrolit (The effect of the think pair share learning model on students' communication skills in electrolyte and non-electrolyte solutions). Jurnal Pendidikan Kimia, 3(1), 8193.

Febrianita, N. K. I. (2019). Keefektifan blanded learning berbasis project dan gaya belajar terhadap keterampilan berpikir kritis dalam pembelajaran dasar desain grafis pada siswa SMK (The effectiveness of project-based blended learning and learning styles on critical thinking skills in basic learning of graphic design in vocational students). Tesis. Tidak diterbitkan. Singaraja: Program Pascasarjana Universitas Pendidikan Ganesha.

Ferrari, J. R., Johnson, J. L., \& McCown, W. G. (1995). Procrastination and task avoidance theory, research, and treatment. New York, NY: Springer.

Hidayat, F., Syah, N., Apdeni, R., \& Kusumaningrum, I. (2018). Pengaruh prokrastinasi terhadap hasil belajar menggambar konstruksi kolom dan balok beton bertulang siswa kelas XI TGB 2 SMKN 1 Pariaman (The effect of procrastination on the learning outcomes of drawing the construction of columns and reinforced concrete beams of class XI TGB 2 SMKN 1 Pariaman). Journal of Civil Engineering and Vocational Education, 5(2), 2218-2222.

Horton, W. (2006). E-learning by design. CA: Pfeiffer, John Wiley and Sons, Inc. 
Ihsan, M. S., Ramdani, A., \& Hadisaputra, S. (2019). Pengembangan e-learning pada pembelajaran kimia untuk meningkatkan kemampuan berpikir kritis peserta didik (Development of e-learning in chemistry learning to improve students' critical thinking skills). Jurnal Pijar MIPA, 14(2), 84 - 87.

Lewis, D. G. (1968). Experimental design in education. London: University of London Press Ltd.

Lindblom-Ylännea, S., Saariahoa, E., Inkinena, M., Anne-Haarala-Muhonenb, \& Hailikaria, T. (2015). Academic procrastinators, strategic delayers and something betwixt and between: An interview study. Frontline Learning Research, 3(2), 47-62.

Mahasneh, A. M., \& Alwan, A. F. (2018). The effect of project-based learning on student teacher self-efficacy and achievement. International Journal of Instruction, 11(3), 511-524.

Millgram, N. A. (1991). Procrastination. Ensyclopedia of Human Biology, 6, 149- 155.

Munawaroh, M. L., Alhadi, S., \& Eka Saputra, W. N. (2017). Tingkat prokrastinasi akademik siswa Sekolah Menengah Pertama Muhammadiyah 9 Yogyakarta (The level of academic procrastination of students at Muhammadiyah 9 Yogyakarta Junior High School). Jurnal Kajian Bimbingan dan Konseling, 2(1), 2017, 26-31.

Naidu, S. (2006). E-learning: A guidebook of principles, procedures, and practices (Revision Editioni, 2006). New delhi: Commonwealth Educational Media Center.

Nurkhaliza, G. N., Hamid, A., \& Suharto, B. (2018). Meningkatkan berpikir kritis melalui model cooperative script dikolaborasi dengan model think pair share (TPS) berbantuan LKPD level representasi kimia materi larutan penyangga (Improve critical thinking through a cooperative script model collaborated with a think pair share (TPS) model assisted by the students' worksheet level of chemical representation of the buffer solution material). Journal of Chemistry And Education, 2(1), 25-32.

Oecd. (2019). Pisa 2018. Retrieved 12 December, 2019 from https://www.oecd.org/pisa

Ojo, A. A. (2019). The impact of procrastination on students academic performance in secondary schools. International Journal of Sociology and Anthropology Research, 5(1), 17-22.

Puspendik. (2019). Laporan hasil ujian nasional (National exam results report). Retrieved 10 January, 2019 from https://hasilun.puspendik.kemdikbud.go.id

Putra, G. P. A. (2017). Pengaruh model pembelajaran berbasis projek terhadap hasil belajar animasi tiga dimensi ditinjau dari kecerdasan spasial siswa kelas XI SMKN 1 Sukawati (The effect of project-based learning models on learning outcomes of threedimensional animation in terms of the spatial intelligence of class XI students of SMKN 1 Sukawati). Tesis. Tidak diterbitkan. Singaraja: Program Pascasarjana Universitas Pendidikan Ganesha.

Putri, I. N. A., \& Fadiawatia, N. \& Syamsuria, M. M. F. (2019). Using projects-based learning in improving students' critical thinking skills to recycle waste cooking oil. International Journal of Chemistry Education Research, 3(1), 23-28. 
Rajan, K. P., Gopanna, A., \& Thomas, S. P. (2019). A project based learning (pbl) approach involving pet recycling in chemical engineering education. Recycling, 4(10), $1-16$.

Rowe, M. P., Gillespie, B. M., Harris, K. R., Koether, S. D., Shannon, L. J., \& Rose, L. A. (2015). Redesigning a general education science course to promote critical thinking. CBE-Life Sciences Education, 14, 1-12.

Safitri, A. D., \& Suparwoto. (2018). Enhancing senior high school students' creative thinking skills using project based e-learning. Journal of Physics: Conference Series, 1097(1), 1-6.

Sani, R. A. (2013). Inovasi pembelajaran (Learning Innovation). Bumi Aksara: Jakarta

Santyasa, I W. (2007). Model-model pembelajaran inovatif (Innovative learning models). Makalah. Disajikan dalam pelatihan tentang penelitian tindakan kelas bagi guru-guru SMP dan SMA pada 29 Juni s.d. 1 Juli 2007 di Nusa Penida.

Santyasa, I W. (2019). Metodologi penelitian pendidikan (Research method in education). Singaraja: Undiksha Press.

Santyasa, I. W., Rapi, N. K., \& Sara, I. W. W. (2020). Project based learning and academic procrastination of students in learning physics. International Journal of Instruction, 13(1), 489-508.

Slameto. (2003). Belajar dan faktor-faktor yang mempengaruhinya. Jakarta : PT Rineka Cipta.

Solomon, L. J., \& Rothblum, E.D. (1984). Academic procrastination: Frequency and cognitive-behavioral correlates. Journal of Counseling Psychology, 31, 504-510.

The George Lucas Educational Foundation. (2007). Instructional module project based learning. Retrieved 02 January, 2020 From http//www.edutopia.org.modules/ $\mathrm{PBL} /$ whatpbl.php.

Wena, M. (2011). Strategi pembelajaran inovatif kontemporer (Contemporary innovative learning strategies). Jakarta : Bumi Aksara.

Widyaningsih, S. W., \& Yusuf, I. (2019). Implementation of project-based learning (pjbl) assisted by e-learning through lesson study activities to improve the quality of learning in physics learning planning courses (Implementation of project-based learning (pjbl) assisted by e-learning through lesson study activities to improve the quality of learning in physics learning planning courses). International Journal of Higher Education, 9(1), 60-68.

Yao, J., Sun, H., Tian,Y., \& Gu, H. (2019). Project-based learning in chinese middleschool students is more effective than the traditional teaching method: An experimental study. SIEF, 2(2), 115-121. 